\title{
PEMBELAJARAN IPA BERBASIS MULTIMEDIA INTERAKTIF UNTUK MENINGKATKAN MINAT DAN PRESTASI BELAJAR SISWA
}

\author{
Rohmani $^{1}$ \\ ${ }^{1}$ Program Studi Pendidikan Guru Sekolah Dasar STKIP Muhammadiyah Kotabumi \\ email: rohman.orgos@gmail.com
}

\begin{abstract}
This paper aims to study science learning using interactive multimedia based on the level of interest in students learning. The learning interest is one of the determining factors of student learning outcomes. The students who have high learning interest in a lesson will have better outcomes than the students who have low learning interest. The ability of a teacher to help improve student learning interest is needed to improve student learning achievement. Selection of the right learning media is one of the way to help students improve their learning interest in a lesson. Interesting and interactive learning media will make students interested in using the media, so that the students' interest in learning will be indirectly more increased than before using the learning media. Interactive learning media can make students to do various movements such as eye movements in observing something that is on the learning media and also the brain movements for thinking, thus the students will be able to stay focus on the material that is being studied. The media that is capable of carrying out these functions which are then referred to as interactive multimedia.
\end{abstract}

Keywords: multimedia learning, interactive multimedia, student learning interest, student achievement.

\section{PENDAHULUAN}

Pendidikan merupakan hal yang harus dimiliki oleh setiap anak sebagai bekal untuk menjalani kehidupan dimasa yang akan datang. Semakin bertambah usia anak, akan semakin kompleks masalah yang akan mereka hadapi. Jika mereka tidak memiliki pengetahuan yang cukup untuk menghadapi permasalahan yang sedang dihadapi, akan berdampak negatif pada masa depan anak tersebut. Pendidikan formal yang ada di sekolah merupakan salah satu sarana siswa untuk memeroleh suatu ilmu pengetahuan. Permasalahan yang timbul ketika siswa berada di lingkungan sekolah selama proses pembelajaran berlangsung, yaitu siswa seharusnya memeroleh suatu pengetahuan. Namun, pengetahuan tersebut tidak diperoleh karena siswa tersebut tidak fokus dan tidak memiliki minat untuk memeroleh pengetahuan tersebut. Kondisi ini akan berdampak pada hasil belajar siswa yang tidak maksimal.

Minat belajar siswa akan memengaruhi hasil belajar siswa, hal ini sesuai dengan pendapat Hawley dalam Wardiana (2004:149) bahwa siswa yang memiliki minat belajar tinggi akan melakukan 
kegiatan lebih banyak dan lebih cepat, dibandingkan dengan siswa yang kurang termotivasi dalam belajar. Salah satu cara untuk menarik minat belajar siswa, yaitu dengan pembelajaran menggunakan media yang menarik dan interaktif.

Definisi media menurut Hamzah dan Nina (2011:122) adalah segala bentuk alat komunikasi yang dapat digunakan untuk menyampaikan informasi dari sumber ke peserta didik. Media dalam pengertian lain diartikan sebagai perantara seperti yang diungkapkan oleh Munandi (2013:8) bahwa media adalah segala sesuatu yang dapat menyampaikan dan menyalurkan pesan dari sumber secara terencana sehingga tercipta lingkungan belajar yang kondusif dan penerimanya dapat melakukan proses belajar secara efisien dan efektif. Dari kedua pengertian di atas dapat dipahami bahwa media pembelajaran adalah alat bantu apa saja yang dapat dijadikan sebagai penyalur pesan untuk memperoleh hasil pembelajaran yang maksimal

Berbagai penelitian pengembangan media pembelajaran sudah dilakukan, tetapi sebagian besar penelitian pengembangan media pembelajaran tersebut hanya memfokuskan pada pokok bahasan materi tertentu. Dengan demikian, guru sulit memeroleh media pembelajaran yang lengkap untuk bahan pembelajaran di kelas. Dalam hal ini guru dituntut untuk mampu mengembangkan sendiri media pembelajaran yang sesuai dengan materi yang akan disampaikan di kelas. Masalah yang timbul ketika guru dituntut untuk mengembangkan media pembelajaran sendiri adalah kurangnya ketersediaan waktu dan juga SDM guru yang belum menguasai teknologi pengembangan media.

Pelajaran IPA merupakan pelajaran yang membutuhkan visualisasi dari suatu objek karena benda yang dipelajari ada di alam, tetapi terkadang sulit untuk menghadirkan di kelas. Untuk membantu kesulitan tersebut maka dibutuhkan suatu media yang mampu menggantikan benda aslinya ke dalam kelas. Tantangan yang harus dihadapi adalah bagaimana cara menghadirkan media pembelajaran yang di dalamnya memuat objek-objek di alam dengan bentuk yang menyerupai objek aslinya.

\section{PEMBAHASAN}

\section{Pembelajaran IPA Konvensional}

Kurikulum yang ada di Indonesia selalu berkembang dari waktu ke waktu. Perkembangan kurikulum ini didasari dengan tuntutan era milenial. Pembelajaran IPA konvensional yang dimaksud dalam hal ini adalah pembelajaran yang gurunya dalam mentransfer ilmu kepada siswa dengan metode ceramah. Hal ini seperti yang dikemukakan oleh Roestiyah N.K. (1998) bahwa cara mengajar yang paling tradisional dan telah lama dijalankan dalam sejarah 
pendidikan ialah cara mengajar dengan ceramah

Metode ceramah jika digunakan dalam pelajaran IPA memiliki beberapa kekurangan di antaranya siswa hanya mendengar saja tanpa melihat bentuk objek aslinya sehingga siswa akan mengalami kesulitan dalam membayangkan suatu objek yang sedang dibicarakan oleh guru. Seperti yang diungkapkan oleh Sanjaya (2006:148) bahwa kekurangan dari metode ceramah adalah materi yang dikuasai siswa dari hasil ceramah akan terbatas pada apa yang dikuasai guru. Di samping itu metode ceramah yang tidak disertai peragaan dapat mengakibatkan terjadinya verbalisme.

Pembelajaran IPA konvensional juga dapat mengakibatkan siswa tidak memiliki minat untuk mempelajarinya karena hanya merupakan cerita dan terkesan membosankan. Padahal jika dikemas dengan baik, pelajaran IPA akan sangat menyenangkan. Hal ini disebabkan yang dipelajarinya adalah alam sekitar yang begitu luas.

Pelajaran IPA yang selalu berkembang dari waktu ke waktu menuntut seorang guru harus terus meng-update pengetahuannya. Pembelajaran IPA konvensional yang hanya menggunakan buku paket dan LKS akan sangat tertinggal dari perkembangan ilmu IPA itu sendiri. Oleh karena itu, guru yang menjadi pusat dari proses pembelajaran IPA harus mampu untuk membuka wawasan dan mengubah metode ceramah dengan metode lain yang lebih efektif dan menyenangkan.

\section{Faktor yang Memengaruhi Proses Belajar}

Proses belajar setiap siswa berbeda beda dan ini sangat kondisional. Menurut Sutikno (2013:16) ada beberapa faktor yang memengaruhi proses belajar siswa. Faktor tersebut dapat datang dari dalam diri individu yang belajar (internal) maupun faktor yang berasal dari luar diri individu (eksternal) atau bisa saja gabungan dari faktor-faktor tersebut. Berikut uraian dari factor-faktor tersebut.

1. Faktor dari dalam Diri Individu (Internal)

Faktor yang berasal dari dalam diri individu (faktor internal) dibedakan menjadi dua, yaitu faktor jasmaniah dan faktor psikologis. Kedua faktor ini berada di dalam diri peserta didik yang hanya diketahui secara pasti oleh peserta didik tersebut. Faktor jasmaniah atau faktor fisiologis merupakan kondisi fisik yang sangat berpengaruh terhadap proses maupun prestasi belajar anak. Faktor jasmaniah adalah faktor kesehatan, faktor cacat tubuh, dan faktor kelelahan. Siswa dalam kondisi kesahatan sedang terganggu akan mengalami kesulitan belajar dibandingkan dengan saat kondisi kesehatannya tidak terganggu. Hal ini harus menjadi perhatian dari pihak sekolah maupun orang tua untuk memberikan 
pengertian kepada siswa tentang pentingnya untuk menjaga kesehatan.

\section{Faktor dari Luar Diri Individu (Faktor Eksternal)}

Faktor eksternal yang memengaruhi proses dan hasil belajar terdiri dari faktor keluarga, faktor sekolah, dan faktor masyarakat. Ketiga faktor ini akan sangat memengaruhi keberhasilan belajar siswa. Faktor keluarga meliputi cara orang tua mendidik, relasi antaranggota keluarga, suasana rumah tangga, dan keadaan ekonomi keluarga. Siswa yang berada dalam kondisi ekonomi berkecukupan dan suasanya keluarga yang nyaman serta orang tuanya perhatian akan pendidikan anaknya akan selalu memastikan anaknya belajar dengan baik dan memberikan yang terbaik untuk anaknya sehingga siswa tersebut tidak mengalami kesulitan belajar. Berbeda dengan siswa dalam kondisi ekonomi yang kekurangan serta kondisi lingkungan keluarga yang kurang kondusif dan juga kurang mendapat perhatian dari orang tua. Siswa tersebut akan mengalami beberapa kesulitan belajar. Kesulitan belajar tersebut di antaranya kurangnya waktu belajar karena harus membantu pekerjaan orang tua. Selain itu juga kurangnya ketersedian literatur sumber belajar di rumah, tidak fokus saat belajar karena tidak kondusifnya lingkungan keluarga dan sebagainya.
Faktor sekolah yang memengaruhi proses dan hasil belajar diantaranya kurikulum, keadaan gedung, waktu sekolah, metode pembelajaran, hubungan antarguru dan siswa dan hubungan antara siswa dengan siswa. Faktor sekolah ini merupakan faktor yang sangat vital yang mempengaruhi proses belajar siswa. Faktor masyarakat adalah kehidupan masyarakat di sekitar siswa berada. Jika siswa berada di lingkungan yang baik, akan berpengaruh baik pula bagi siswa dan juga sebaliknya jika siswa berada di lingkungan yang kurang baik seperti lingkungan yang memiliki kebisaaan kebisaaan yang tidak baik seperti berjudi, narkoba, dan sebagainya, akan berpengaruh jelek terhadap anak tersebut.

\section{Prestasi Belajar Siswa}

\section{Pengertian Prestasi Belajar}

Pengertian prestasi belajar menurut Winkel dalam Sunarto (1996:162) bahwa prestasi belajar adalah suatu bukti keberhasilan belajar atau kemampuan seorang siswa dalam melakukan kegiatan belajarnya sesuai dengan bobot yang dicapainya. Selanjutnya menurut Nurkencana (1986:62) bahwa prestasi belajar adalah hasil yang telah dicapai atau diperoleh anak berupa nilai mata pelajaran. Ditambahkan bahwa prestasi belajar merupakan hasil yang mengakibatkan perubahan dalam diri 
individu sebagai hasil dari aktivitas dalam belajar.

Dari kedua definisi pengertian belajar tersebut, dapat disimpulkan bahwa prestasi belajar siswa dapat diartikan sebagai suatu bukti kemampuan dan keterampilan siswa dalam kegiatan belajarnya yang ditunjukkan oleh nilai berupa angka ataupun huruf, simbol dan kalimat dan juga mengakibatkan perubahan dari dalam diri siswa.

Prestasi belajar siswa rendah dapat diketahui dari nilai siswa yang kurang atau di bawah standar ketuntasan minimal, sedangkan prestasi belajar siswa tinggi dapat dilihat dari nilai siswa yang berada di atas ketentuan minimal. Prestasi belajar siswa dipengaruhi oleh beberapa faktor, seperti yang diungkapkan oleh Masrun dan Martiniah (dalam Khodijah (2014:58) bahwa faktor-faktor yang memengaruhi prestasi belajar siswa dapat digolongkan menjadi beberapa diantaranya: (1) kemampuan bawaan anak; (2) kondisi fisik dan psikis anak; (3) kemauan belajar anak; (4) sikap murid terhadap guru dan mata pelajaran serta pengertian mereka mengenai kemajuan mereka sendiri dan (5) bimbingan.

Berdasarkan kelima faktor yang memengaruhi prestasi belajar tersebut, dapat disimpulkan bahwa kempuan serta kondisi fisik dan psikis siswa adalah faktor yang melekat pada diri anak, sedangkan faktor kemauan belajar, sikap serta bimbingan dari pendidik dapat diupayakan oleh pihak luar. Dengan demikian, peserta didik mampu untuk memeroleh prestasi belajar yang lebih baik lagi.

\section{Minat Belajar Siswa \\ Pengertian Minat}

Menurut Ahmadi (2009:148) minat adalah sikap jiwa orang-seorang termasuk ketiga fungsi jiwanya (kognisi, konasi, dan emosi), yang tertuju pada sesuatu dan dalam hubungan itu unsur perasaan yang kuat. Selanjutnya menurut Djaali (2008:121) minat adalah rasa lebih suka dan rasa ketertarikan pada suatu hal atau aktivitas, tanpa ada yang menyuruh. Dari kedua pendapat tersebut dapat diartikan bahwa minat sebagai sikap seseorang terhadap sesuatu hal yang ditunjukan dengan ketertarikan pada hal tersebut tanpa ada paksaan dari pihak lain.

\section{Pengertian Belajar}

Menurut Djamarah (2011:13) definisi belajar adalah serangkaian kegiatan jiwa raga untuk memeroleh suatu perubahan tingkah laku sebagai hasi dari pengalaman individu dalam interaksi dengan lingkungannya yang menyangkut kognitif, afektif, dan psikomotor. Selanjutnya menurut Khodijah (2014:50) belajar adalah sebuah proses yang memungkinkan seseorang memperoleh dan membentuk kompetensi, ketrampilan, dan sikap yang baru melibatkan prosesproses 
mental internal yang mengakibatkan perubahan perilaku dan sifatnya relatif permanen.

Dari kedua definisi tersebut maka dapat diartikan bahwa belajar sebagai bentuk perubahan diri seseorang sebagai hasil dari proses kegiatan jiwa raga. Perubahan tersebut melibatkan perubahan perilaku, pengetahuan, dan juga perubahan pengalaman yang bersifat relatif tetap. Berdasarkan definisi minat dan definisi belajar maka dapat dikatakan bahwa minat belajar sebagai ketertarikan seseorang untuk memeroleh suatu pengetahuan, keterampilan, dan tingkah laku dengan tanpa adanya paksaan.

\section{Faktor-Faktor yang Memengaruhi Minat Belajar}

Minat belajar seseorang tidak timbul begitu saja, tetapi ada beberapa faktor yang memengaruhinya. Syah (2003:132) membedakannya menjadi tiga macam, yaitu:

a) Faktor internal

Faktor internal dalah faktor dari dalam diri siswa yang meliputi dua aspek, yakni:

\section{1) Aspek fisiologis}

Kondisi jasmani dan tegangan otot yang menandai tingkat kebugaran tubuh siswa. Hal ini dapat memengaruhi semangat dan intensitas siswa dalam pembelajaran.
2) Aspek psikologis

Aspek psikologis adalah aspek yang berasal dari dalam diri siswa yang terdiri dari, intelegensi, bakat siswa, sikap siswa, minat siswa, motivasi siswa.

b) Faktor Eksternal Siswa

Faktor eksternal terdiri dari dua macam, yaitu faktor lingkungan sosial dan faktor lingkungan nonsosial

1) Lingkungan Sosial

Lingkungan sosial terdiri dari lingkungan sekolah, keluarga, masyarakat dan teman sekelas

2) Lingkungan Nonsosial

Lingkungan sosial terdiri dari gedung sekolah dan letaknya, faktor materi pelajaran, waktu belajar, keadaan rumah tempat tinggal, alat-alat belajar.

c) Faktor Pendekatan Belajar

Faktor pendekatan belajar, yaitu segala sesuatu cara atau strategi yang digunakan siswa dalam menunjang keefektifan dan efisiensi proses mempelajari materi tertentu.

Berdasarkan ketiga faktor yang dikemukakan oleh Syah tersebut, terdapat dua faktor yang dapat diupayakan peningkatannya oleh pihak pendidik, yaitu faktor eksternal dan faktor pendekatan belajar, sedangkan faktor internal hanya 
siswa itu sendiri yang dapat menentukan. Walaupun faktor internal hanya siswa tersebut yang dapat mengubah peningkatannya, pihak pendidik pun juga memiliki peran untuk membantu peningkatan minat belajar siswa dari faktor internal tersebut.

\section{Penggunaan Media dalam Proses Pembelajaran}

Proses pembelajaran di kelas yang menyenangkan dapat memengaruhi minat belajar siswa kearah yang positif. Pembelajaran yang menyenangkan dalam konteks ini adalah pembelajaran yang bahan pelajarannya disenangi untuk dipelajari oleh siswa. Seperti yang dikemukakan oleh Slameto (2010:182) bahwa minat mempunyai pengaruh yang sangat besar terhadap belajar. Jika bahan pelajaran yang dipelajari tidak sesuai dengan minat siswa, siswa tidak akan belajar dengan sebaik-baiknya karena tidak ada daya tarik baginya.

Bahan pelajaran supaya disenangi juga harus dikemas dengan baik sehingga siswa akan tertarik untuk terus mempelajarinya. Ketertarikan siswa terhadap suatu bahan pelajaran akan berdampak pada hasil belajar siswa karena selama proses pembelajaran di kelas siswa akan selalu memperhatikan apa yang sedang dipelajarinya. Tingginya perhatian siswa terhadap suatu materi yang sedang dipelajari akan berdampak pada pemahaman siswa yang lebih dalam dari materi tersebut. Suryabrata (2010:14) me- ngatakan perhatian adalah banyak sedikitnya kesadaran yang menyertai sesuatu aktivitas yang dilakukan. Perhatian merupakan pemusatan tenaga atau kekuatan jiwa tertentu kepada suatu objek, atau pendayagunaan kesadaran untuk menyertai suatu aktivitas.

Menurut Suryabrata (2010:18) fungsi dari perhatian dalam belajar adalah bentuk aktivitas yang disertai dengan perhatian intensif akan lebih sukses dan prestasinya lebih tinggi. Alangkah baiknya apabila tiap pelajaran dapat diterima siswa dengan perhatian yang cukup intensif. Berdasarkan penjelasan tersebut, dapat dikatakan bahwa salah satu tugas penting guru, yaitu mampu merangsang perhatian siswanya di dalam proses pembelajaran. Penggunaan media dalam proses pembelajaran merupakan salah bentuk upaya guru dalam merangsang perhatian siswa agar mau memperhatikan materi yang akan dipelajari. Peran guru dalam memilih media pembelajaran sangat penting. Jika guru memilih media pembelajaran yang tidak tepat, siswa juga tidak akan tertarik untuk memperhatikan materi yang sedang dibahas.

Usaha memanfaatkan media sebagai alat bantu, Edgar Dale mengadakan klasifikasi menurut tingkat dari yang paling konkret ke yang paling abstrak dan ditunjukan pada Gambar 1 kerucut pembelajaran. 


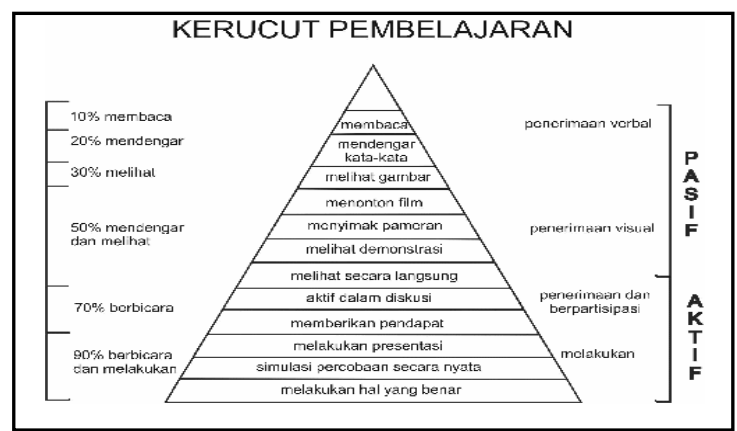

Gambar 1

Kerucut Pembelajaran

Pada Gambar 1 Edgar Dale melukiskan bahwa semakin konkret siswa mempelajari bahan pelajaran maka semakin banyaklah pengalaman yang didapatkan. Namun, sebaliknya, jika semakin abstrak siswa mempelajari bahan pelajaran, semakin sedikit pula pengalaman yang akan didapatkan oleh siswa. Gambar 1 juga memperlihatkan bahwa saat penggunaan media pembelajaran lebih konkret atau dengan pengalaman langsung maka pesan (informasi) pada proses pembelajaran yang disampaikan guru kepada siswa akan tersampaikan dengan baik. Sebaliknya jika penggunaan media pembelajaran semakin abstrak, pesan akan sulit untuk diterima siswa. Dengan kata lain, siswa menghadapi kesulitan dalam memahami dan mencerna apa yang disampaikan oleh guru.

Pelajaran IPA yang bahan ajarnya berupa benda atau objek yang ada di alam, jika diajarkan secara konvensional, akan bersifat abstrak dan menyebabkan siswa sulit untuk memahami. Oleh sebab itu, berdasarkan kerucut Edgar Dale akan sangat lebih efektif lagi jika bahan ajar IPA disampaikan kepada siswa dengan menggunakan alat bantu. Alat bantu tersebut menjadikan bahan ajar IPA tersebut menjadi lebih konkret agar siswa lebih mudah untuk menerima dan menyenangi pelajaran IPA.

\section{Multimedia Interaktif}

Pembelajaran IPA yang menyenangkan dan mampu menarik perhatian siswa merupakan faktor yang dapat meningkatkan minat belajar siswa. Pengemasan bahan ajar yang menyenangkan dan menarik dapat dikemas dalam bentuk multimedia interaktif. Multimedia menurut Hoftetter dalam Suyanto (2005:21) diartikan sebagai pemanfaatan komputer untuk membuat dan menggabungkan teks, grafik, audio, gambar bergerak (video dan animasi) dengan menggunakan link dan perangkat (tool) yang memungkinkan pemakai melakukan navigasi, berinteraksi, dan berkomunikasi. Berdasarkan definisi multimedia tersebut, pembelajaran IPA yang memuat objek-objek alam yang begitu luas dapat ditampilkan di kelas dalam bentuk audiovisual dan tidak hanya verbal saja sebagaimana yang terjadi pada pembelajaran konvensional.

Kelebihan penggunaan multimedia interaktif menurut Munandi (2013:152) di antaranya adalah saat siswa menggunakan multimedia interaktif. Siswa diajak terlibat secara auditif, visual, dan kinetik sehingga dengan pelibatan ini dimungkinkan infor- 
masi atau pesan mudah dimengerti. Adapun manfaat yang bisa diperoleh dari penggunaan multimedia interaktif menurut Ariani dan Haryanto (2010:26) adalah proses pembelajaran menjadi menarik, lebih interaktif, jumlah waktu mengajar (ceramah) dapat dikurangi, kualitas belajar siswa dapat lebih termotivasi dan terdongkrak serta belajar mengajar dapat dilakukan dimana saja dan kapan saja (sangat fleksibel), serta sikap dan perhatian belajar siswa dapat ditingkatkan dan dipusatkan.

Berdasarkan kelebihan dan manfaat yang bisa diperoleh dari penggunaan multimedia interaktif, sudah semestinya guru dalam proses pembelajaran menggunakan media supaya minat belajar dan prestasi belajar peserta didik dapat mengalami peningkatan. Fungsi dari penggunaan multimedia dalam pembelajaran menurut Warsita (2008:136) dibagi menjadi tujuh fungsi, yaitu: sebagai gudang ilmu,sebagai alat bantu pembelajaran, sebagai fasilitas pendidikan, sebagai standar kompetensi, sebagai penunjang administrasi, sebagai alat manajemen sekolah, dan sebagai infrastruktur pendidikan. Multimedia sebagai gudang ilmu dan alat bantu pembelajaran akan sangat membantu siswa dalam memeroleh pemahaman dan pengetahuan yang lebih banyak daripada pembelajaran dengan menggunakan meteode ceramah yang pengetahuannya terbatas pada pengetahuan guru.
Multimedia interaktif mengandung unsur-unsur yang dapat merangsang perhatian siswa karena di dalam multimedia interaktif tidak hanya terdapat grafik atau gambar saja, melainkan juga terdapat suara, animasi, video dan juga interaksi. Multimedia interaktif memiliki kedudukan yang sangat penting dalam proses pembelajaran. Hal ini seperti yang diungkapkan oleh Munandi (2013:152) bahwa kedudukan media sepenuhnya melayani kebutuhan belajar siswa (pola bermedia). Artinya, untuk beberapa hal media pembelajaran dapat menggantikan fungsi guru terutama sebagai sumber belajar. Salah satu media yang dapat menjalankan fungsi demikian, yaitu program multimedia interaktif yang selanjutnya disebut multimedia interaktif

\section{Multimedia Pembelajaran Sebagai Alat Meningkatkan Minat Belajar Dan Prestasi Belajar Siswa}

Multimedia dengan berbagai macam kelebihan, manfaat, dan juga fungsinya dalam proses pembelajaran, akan dapat membantu dalam meningkatkan minat belajar siswa selama proses pembelajaran IPA di kelas. Hal ini didasari dari siswa yang awalnya tidak memiliki minat untuk mempelajari materi IPA karena beranggapan IPA selalu menjadi pelajaran yang bersifat cerita dari ceramah guru, akan menjadi lebih berminat ketika pada saat pelajaran, siswa 
melihat dan mendengar materi IPA yang disajikan dalam multimedia interaktif. Fokus siswa akan tertuju pada apa yang ditampilkan dalam multimedia pembelajaran sehingga dengan tanpa dipaksa untuk memperhatikan, siswa dengan kesadarannya sendiri akan memperhatikan pelajaran tersebut karena dianggap menarik.

Ketika minat belajar siswa sudah tumbuh saat pelajaran yang dikemas dalam bentuk multimedia pembelajaran, saat itulah proses belajar sudah terjadi. Faktor penentu yang berada di dalam diri siswa, yaitu faktor internal akan dengan sendirinya mengalami perubahan secara bertahap ke arah yang lebih baik. Pada saat faktor internal siswa selama proses belajar sudah membaik maka secara tidak langsung prestasi belajar siswa juga mengikuti perubahan ke arah yang lebih baik. Hal ini akan memungkinkan terjadinya peningkatan prestasi belajar siswa.

Penelitian yang pernah dilakukan oleh Hanim (2016) tentang pengaruh penggunaan multimedia terhadap peningkatan hasil belajar menunjukkan hasil, yaitu pada kelas eksperimen diperoleh mean 74,24 dengan standar deviasi 7,267 lebih besar daripada kelas kontrol yang memiliki mean 60,21 dengan standar deviasi 9,955. Hasil gain score menunjukkan selisih antara nilai pretes dan postes didapatkan pada kelas ekperimen dengan hasil rata-rata gain score, yaitu 0,7. Hasil tersebut menunjukan bahwa penggunaan multimedia interaktif dalam pembelajaran berpengaruh pada hasil belajar siswa yang sangat signifikan.

Penelitian tentang pengaruh minat belajar terhadap prestasi belajar telah dilakukan oleh Rusmiati (2017) dengan hasil penelitian, yaitu skor angket $\mathrm{t}$ minat belajar pelajaran katagori tinggi sebesar 37,50\%, memperoleh skor katagori sedang sebesar $32,50 \%$, dan perolehan skor kategori rendah sebesar $30,00 \%$. Dari data hasil penelitian tersebut maka dapat disimpulkan bahwa minat belajar siswa berada pada kategori sedang. Selanjutnya untuk prestasi belajar siswa diperoleh data siswa yang mendapatkan nilai kategori sedang sebesar $77,50 \%$, memperoleh nilai kategori tinggi sebesar 22,50\%, dan perolehan nilai kategori rendah sebesar $0,00 \%$. Berdasarkan data tersebut diketahui bahwa prestasi belajar siswa kategori sedang sebesar 77,50\%. Presentase tersebut telah melebihi 50\% dari jumlah seluruhnya.

Oleh karena itu, dapat disimpulkan bahwa prestasi belajar siswa berada pada kategori sedang. Dari kedua hasil analisis korelasi antara hasil angket dan hasil dokumentasi nilai raport siswa, diketahui bahwa minat belajar siswa mempunyai pengaruh yang sedang atau cukup terhadap prestasi belajar siswa. Angka indeks korelasi minat belajar dengan prestasi belajar bidang studi ekonomi adalah 0,681. Dari hasil 
penelitian tersebut dapat disimpulkan bahwa minat belajar berpengaruh terhadap prestasi belajar.

Berdasarkan kedua penelitian tersebut, dapat dijelaskan bahwa jika minat belajar siswa rendah, prestasi belajar siswa akan rendah. Jika minat belajar siswa tinggi, prestasi belajar siswa juga akan tinggi. Siswa dengan minat belajar rendah dapat diberikan dorongan agar minat belajarnya meningkat dengan cara pembelajaran dengan menggunakan multimedia. Hal tersebut sesuai dengan penelitian Hanin (2016) bahwa multimedia memiliki pengaruh yang signifikan terhadap prestasi belajar siswa karena selama proses pembelajaran minat belajar siswa meningkat dengan ditampilkan sesuatu yang menarik yang terdapat di dalam multimedia tersebut.

Penggunaan multimedia dalam proses pembelajaran dapat meningkatkan minat dan prestasi belajar siswa. Hal ini dikarenakan multimedia pembelajaran beirisi video, animasi, dan juga interaktif sehingga siswa tertarik untuk mengikuti pembelajaran. Video yang di dalamnya memuat gambar gerak dan suara memungkinkan siswa lebih mudah untuk memahami materi pelajaran daripada hanya melihat gambar yang ada di buku pelajaran saja. Animasi yang di dalamnya berisi simulasi atau peragaan tentang suatu objek yang tidak memungkinkan dilakukan di dalam kelas dapat diperlihatkan dan diatur variabelnya. Dengan demikian, siswa akan tertarik untuk mencoba dan proses ini akan merangsang siswa untuk lebih bersemangat dalam belajar.

\section{KESIMPULAN}

Berdasarkan paparan dari penggunaan multimedia interaktif, minat belajar siswa dan juga prestasi belajar siswa maka dapat diambil kesimpulan bahwa prestasi belajar siswa dipengaruhi oleh beberapa faktor. Salah satu faktornya, yaitu minat belajar siswa. Jika minat belajar siswa meningkat, prestasi belajar juga akan meningkat. Untuk meningkatkan prestasi belajar siswa salah satu upaya yang bisa dilakukan adalah dengan cara meningkatkan minat belajar siswa. Sedangkan salah satu cara meningkatkan minat belajar siswa, yaitu dengan cara pembelajaran dengan menggunakan alat bantu media berupa multimedia interaktif.

Pelajaran IPA akan disenangi siswa jika dalam menyajikan materi IPA dikemas dengan menggunakan media yang tepat, yaitu dalam bentuk multimedia interkatif. Media tersebut di dalamnya memuat bukan hanya gambar saja, melainkan juga berisi video, animasi, dan juga interaksi. Penggunaan multimedia interaktif dalam pembelajaran IPA akan mampu meningkatkan minat belajar siswa dan juga mampu meningkatkan prestasi belajar siswa. 


\section{DAFTAR RUJUKAN}

Djaali. 2008. Psikologi Pendidikan. Jakarta: Bumi Aksara.

Djamarah, Syaiful Bahri. 2011. Psikologi Belajar. Jakarta: Rineka Cipta.

Fitria Hanim, Sumarmi, Ach. Amirudi. 2016. Pengaruh Penggunaan Multimedia Pembelajaran Inerakif Penginderaan Jauh Terhadap Hasil Belajar Geografi. Jurnal Pendidikan.

Hamzah B. dan Nina L. 2011. Teknologi Informasi \& Komunikasi Pembelajaran. Jakarta: PT Bumi Aksara.

Khodijah, Nyayu. 2014. Psikologi Pendidikan. Jakarta: Rajawali Pers.

Munandi, Yudhi. 2013. Media Pembelajran Sebuah Pendekatan Baru. Jakarta: GP Press Group

Nurkancana, Wayan. 1986. Evaluasi Pendidikan. Surabaya: Usaha Nasional

Roestiyah, N.K. 1998. Strategi Belajar Mengajar. Rineka Cipta. Jakarta.

Rusmiati. 2017. "Pengaruh Minat Belajar terhadap Prestasi Belajar Bidang Studi Ekonomi Siswa MA Al Fattah Sumbermulyo." UTILITY: Jurnal Ilmiah Pendidikan dan Ekonomi 34(1): 25491377.

Sanjaya, Wina. 2006. Strategi Pembelajaran. Jakarta: Kencana Prenada Media Group.

Slameto. 2010. Belajar dan Faktor yang Mempengaruhinya. Jakarta: Rineka Cipta.

Sunarto, dkk. 2008. Perkembangan Peserta Didik. Jakarta: Rineka Cipta.

Suryabrata, Sumadi, 2006. Metodologi Penelitian, Jakarta: PT. Raja Grafindo Persada.

Sutikno, Sobry. 2013. Belajar dan Pembelajaran. Lombok: Holistica.

Suyanto, M. 2005. Multimedia Alat Untuk Meningkatkan Keunggulan Bersaing. Yogyakarta: Andi.

Syah, Muhibbin. 2003. Psikologi Belajar. Jakarta: PT Raja Grafindo.

Wardiana, U. 2005. Psikologi Umum. Jakarta: Bina Ilmu.

Warsita, Bambang. 2008. Teknologi Pembelajaran, Landasan dan Aplikasinya. Jakarta: Rineka Cipta. 